\title{
Difference in the Inductions of Duodenal Alkaline Phosphatase by Casein Feeding and by Starch Feeding
}

\author{
Yasuko IsHIKAWA, Michiko SuZUKI, Akifumi ONO, \\ Yukihiro NAKABOU, and Hiroshi HAGIHIRA ${ }^{1}$ \\ Department of Nutrition, School of Medicine, \\ The University of Tokushima, \\ Kuramoto-cho, Tokushima 770, Japan
}

(Received August 28, 1982)

\begin{abstract}
Summary Feeding of starch or casein to rats that had been starved for 4 days resulted in marked increase in duodenal alkaline phosphatase activity in a few hours. In rats with a duodenal blind loop, the enzyme was induced by feeding starch, but not casein.

Conditions leading to hyperglycemia, such as an intragastric administration and an intravenous infusion of glucose, induced duodenal alkaline phosphatase to the same extent and in the same period as starch feeding. Subcutaneous injection of insulin alone did not induce the enzyme.

In chemically sympathectomized rats, the enzyme was induced by starch feeding. In vagotomized or hexamethonium-treated rats, the enzyme was not induced by starch feeding or intragastric administration of glucose solution. On the contrary, subcutaneous injection of carbachol alone induced the enzyme. These results suggest that stimulation of the parasympathetic nervous system via hyperglycemia is important for induction of duodenal alkaline phosphatase by starch feeding. The mechanism of enzyme induction by casein feeding is still unknown.
\end{abstract}

Key Words duodenal alkaline phosphatase, starch feeding, casein feeding, hyperglycemia, sympathectomy, vagotomy

In rats, intestinal alkaline phosphatase is mainly localized in the brush border membrane(1), and its activity is highest in the duodenum, decreasing rapidly toward the ileum $(2,3)$. The enzyme is rapidly induced by protein (4-6) or carbohydrate (7) feeding in rats that have been starved for a few days.

In the present study we examined whether direct contact of a nutrient with the small intestine was necessary for enzyme induction by using rats with a blind loop. We also examined whether the autonomic nervous system was involved in the enzyme induction.

${ }^{1}$ 石川康子, 鈴木道子, 小野章史, 中坊幸弘, 萩平 博 


\section{EXPERIMENTAL}

1) Animals and diets. Male Sprague-Dawley rats weighing about $120 \mathrm{~g}$ were housed in individual cages and kept in a room lighted automatically from $8 \mathrm{AM}$ to 8 PM every day. The animals were given laboratory chow (Oriental yeast Co., Ltd., Osaka, Japan) ad libitum, until they weighed about $250 \mathrm{~g}$. Then, they were starved for 4 days, and then given either $5.5 \mathrm{~g}$ of starch or $5 \mathrm{~g}$ of casein plus $0.5 \mathrm{~g}$ of starch at 10 AM on day 5. Starch was added in the latter case to stimulate appetite, and this amount was found to have no effect on enzyme induction.

2) Construction of an intestinal blind loop. An intestinal blind loop was constructed as reported previously (8) except that it was lengthened to about $13 \mathrm{~cm}$. Animals were used for experiments 3 weeks after the operation.

3) Enzyme assay. Rats were sacrificed by a blow on the head $9 \mathrm{hr}$ after casein feeding or $6 \mathrm{hr}$ after starch feeding. The entire small intestine was removed and washed with cold saline. The first $4 \mathrm{~cm}$ length from the pyrolus was cut off and discarded, and the next $10 \mathrm{~cm}$ length and the blind loop were used for enzyme assay. The segment was everted and the mucosa was scraped off with a slide glass and homogenized in 10 volumes of cold distilled water with a Teflon homogenizer. The homogenate was diluted appropriately and used for enzyme assay and protein determination. Alkaline phosphatase activity was determined by the method of Forstner et al. (9). Protein was measured by the method of Lowry et al. (10) with bovine serum albumin as a standard. Enzyme activity was expressed as $\mu$ moles of inorganic phosphate liberated $/ \mathrm{min} / \mathrm{mg}$ protein. Plasma glucose was determined by the Somogyi-Nelson method (11).

4) Materials. Cycloheximide was purchased from Nakarai Chemicals. Phlorizin and hexamethonium chloride were from Wako Pure Chemical Industries. 6-Hydroxydopamine hydrobromide was from Aldrich Chemical Co. Carbamylcholine chloride (carbachol) was from Sigma Chemical Co. Insulin was from Takeda Chemical Industries. Panamin S was from Otuka Pharmaceutical Co.

\section{RESULTS}

Figure 1 shows the changes with time in activity of duodenal alkaline phosphatase after casein or starch feeding. The activity increased gradually to a maximum $9 \mathrm{hr}$ after casein feeding and $6 \mathrm{hr}$ after starch feeding.

The relations between the extents of enzyme induction and the food intakes are shown in Fig. 2. Good correlations between the two were observed.

Administration of casein or starch to rats that had been starved for 4 days resulted in more than 2-fold increase in duodenal alkaline phosphatase activity (Fig. 3). But in rats with a blind loop, the enzyme in the blind loop was induced by starch, but not by casein. After starvation for 4 days, intragastric administration of $5 \mathrm{ml}$ of $20 \%$ glucose solution twice with an interval of $3 \mathrm{hr}$ between treatments resulted in about 3-fold increase in activity of duodenal alkaline phosphatase. When phlorizin, 


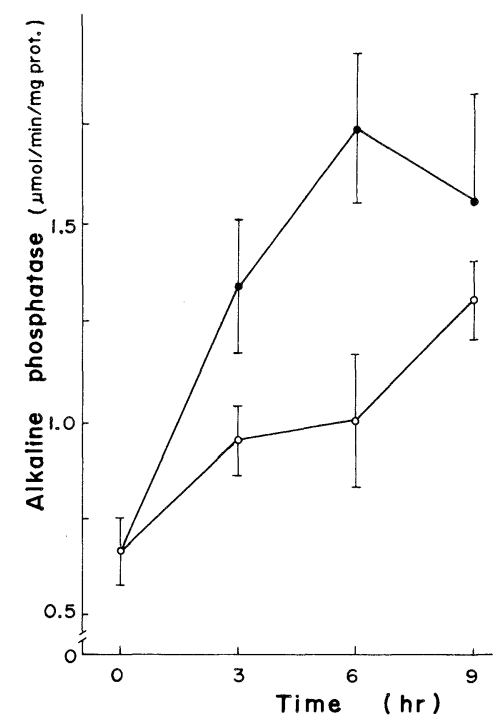

Fig. 1. Time courses of induction of duodenal alkaline phosphatase after casein and starch feeding. Rats were starved from day $0-4$ and fed casein $(O)$ or $\operatorname{starch}(\bullet)$ at $10 \mathrm{AM}$ on day 5 . They were sacrificed at the indicated times. Values are means $\pm \mathrm{SE}$ for 3 rats.

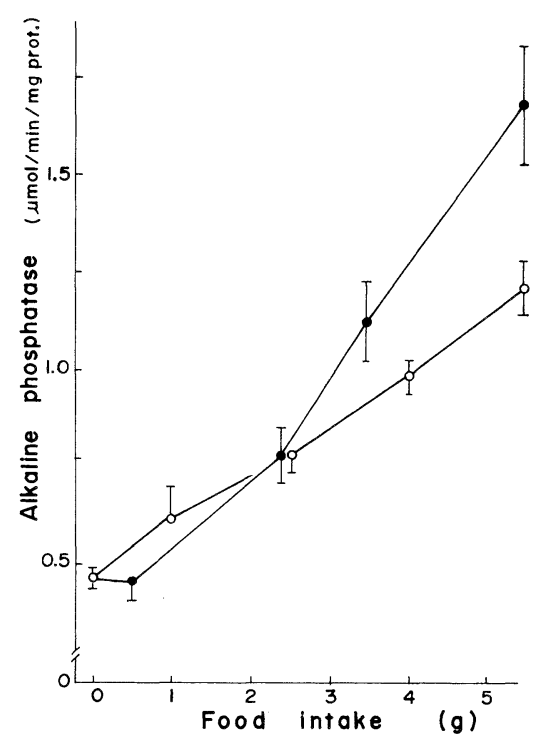

Fig. 2. Effect of food intake on the induction of duodenal alkaline phosphatase. Rats were starved from day $0-4$ and fed $1,2.5,4$, or $5.5 \mathrm{~g}$ casein $(O)$ or $0.5,2.5,3.5$ and $5.5 \mathrm{~g}$ starch (๑) at $10 \mathrm{AM}$ on day 5 . Rats fed starch were killed at $4 \mathrm{PM}$ and those fed casein at 7 PM. Values are means \pm SE for 5 rats.

Vol. 29, No. 1, 1983 


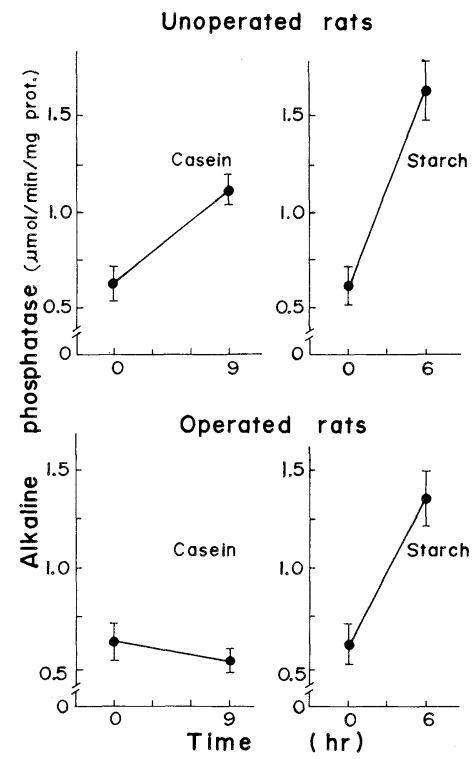

Fig. 3. Inductions of duodenal alkaline phosphatase in rats with a duodenal blind loop after casein and starch feeding. Sham-operated rats (upper) and rats with a blind loop (lower) were fed casein or starch at $10 \mathrm{AM}$ on day 5. Casein-fed rats were killed at 7 PM (left) and starch-fed rats at 4 PM (right). Values are means \pm SE for 7 rats.

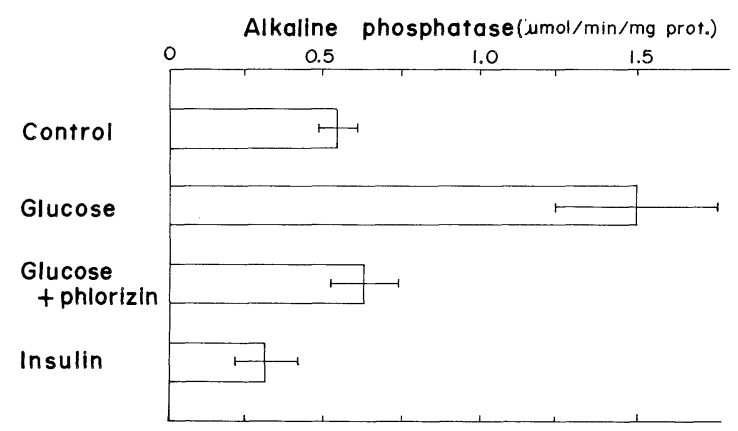

Fig. 4. Effects of glucose solution and insulin on duodenal alkaline phosphatase. Rats were starved for 4 days. Then on day 5 one group was force-fed $5 \mathrm{ml}$ of $20 \%$ glucose solution at $10 \mathrm{AM}$ and the other was force-fed $2 \mathrm{ml}$ of $0.05 \mathrm{M}$ phlorizin suspension in distilled water at $9: 30 \mathrm{AM}$ and $5 \mathrm{ml}$ of $20 \%$ glucose plus $0.025 \mathrm{M}$ phlorizin at $10 \mathrm{AM}$ and $1: 30 \mathrm{PM}$. Insulin $(2 \mathrm{U} / \mathrm{kg})$ was given s.c. at $10 \mathrm{AM}$ on day 5 . Control rats were starved by the time of sacrifice on day 5 . Values are means \pm SE for 5 rats.

a potent inhibitor or intestinal absorption of glucose, was given, subsequent administration of glucose solution did not induce the enzyme. Subcutaneous injection of regular insulin $(2 \mathrm{U} / \mathrm{kg})(12)$ alone did not induce the enzyme (Fig. 4). 


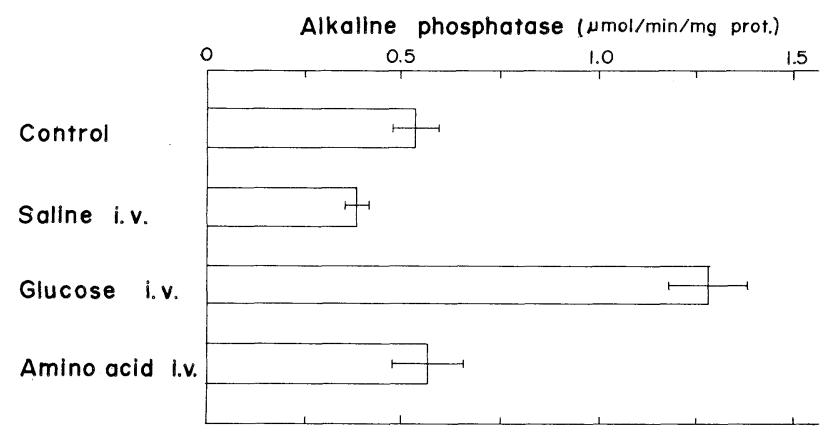

Fig. 5. Effect of continuous intravenous alimentation on duodenal alkaline phosphatase induction. For details, see RESULTS. Values are means \pm SE for 5 rats.

Blood glucose levels at time of sacrifice were $100 \pm 12 \mathrm{mg} / \mathrm{dl}$ (control), $189 \pm 31$ $\mathrm{mg} / \mathrm{dl}$ (+glucose), $130 \pm 10 \mathrm{mg} / \mathrm{dl}$ (+glucose, +phlorizin) and $68 \pm 21 \mathrm{mg} / \mathrm{dl}$ (+insulin), respectively.

A high blood glucose level was maintained by constant glucose infusion into animals after operations as follows: Rats were starved for 4 days and then anesthetized with Nembutal and a silicon tube (o.d. $1 \mathrm{~mm}$, i.d. $0.5 \mathrm{~mm}$ ) was inserted into the jugular vein. The free end of the tube was brought out on the back through the midscapular region and connected to the long-term intravenous feeding apparatus described by Steiger et al. (13). Physiological saline was infused at a rate of $2 \mathrm{ml} / \mathrm{hr}$ overnight. At $10 \mathrm{AM}$ on day 5, the saline solution was changed to $12.5 \%$ glucose solution or Panamine $\mathrm{S}(8.75 \%$ amino acid mixture by the Vuj standard) and the infusion was continued at a flow rate of $3 \mathrm{ml} / \mathrm{hr}$. Alkaline phosphatase activity and blood glucose were determined 6 and $9 \mathrm{hr}$ after the starts of infusion of glucose and Panamine $S$, respectively. Continuous intravenous infusion of glucose solution caused a significant increase in activity of duodenal alkaline phosphatase, whereas infusion of Panamine S did not induce the enzyme (Fig. 5).

Bilateral subdiaphragmatic vagotomy $(14,15)$ was performed to see whether the parasympathetic nervous system was involved in enzyme induction. The operated rats were given laboratory chow and water ad libitum for 3 days and then starved for 4 days. At 10 AM on day 5, they were given starch and casein diets, and sacrificed 6 and $9 \mathrm{hr}$ later, respectively. Since after the operation rats lost their appetite to some extent, $4.5 \mathrm{~g}$ of experimental diet was given to both operated and sham-operated rats in this experiment. The activity of duodenal alkaline phosphatase increased markedly in the sham-operated rats, but not the vagotomized rats (Fig. 6).

Hexamethonium chloride $(60 \mathrm{mg} / \mathrm{kg})(16)$ was injected intraperitoneally into starved rats $1 \mathrm{hr}$ before intragastric administration of $5 \mathrm{ml}$ of $20 \%$ glucose solution, and the same amount of the drug was given once more $3 \mathrm{hr}$ after the first injection. The animals were sacrificed $6 \mathrm{hr}$ after glucose administration. Hexamethonium 


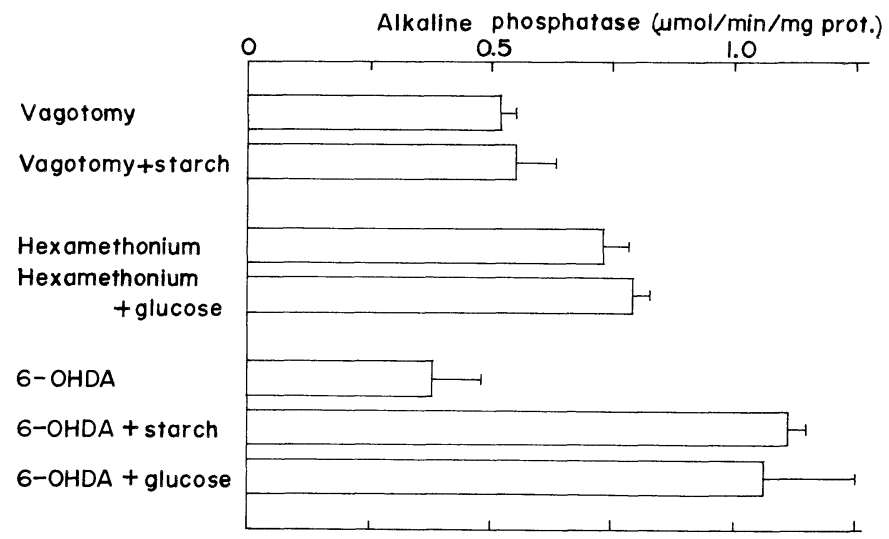

Fig. 6. Effects of stimulation and inhibition of the sympathetic and parasympathetic nervous systems on induction of duodenal alkaline phosphatase by starch feeding or intragastric administration of glucose. Vagotomy and treatments with hexamethonium and 6-hydroxydopamine were performed as described in RESULTS. Animals were starved for 4 days and given starch diet or $5 \mathrm{ml}$ of $20 \%$ glucose solution at $10 \mathrm{AM}$ on day 5 . They were killed at $4 \mathrm{PM}$. Control rats were starved by the time of sacrifice on day 5 . Values are means \pm SE for 5 rats.

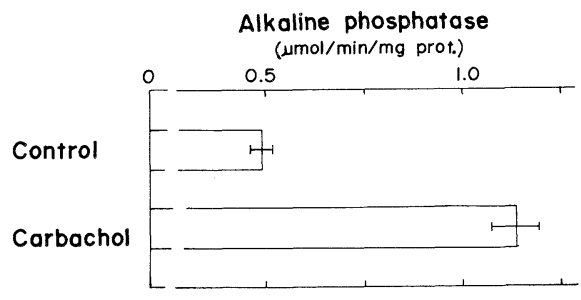

Fig. 7. Effect of carbachol treatment on duodenal alkaline phosphatase induction. Rats were starved for 4 days and then given $0.5 \mathrm{mg} / \mathrm{kg}$ of carbachol s.c. at $10 \mathrm{AM}$ and noon on day 5 , and killed at $4 \mathrm{PM}$. Values are means \pm SE for 5 rats.

treatment inhibited intestinal alkaline phosphatase induction by intragastric administration of glucose (Fig. 6). Carbachol $(0.5 \mathrm{mg} / \mathrm{kg})(17,18)$, a stimulator of parasympathetic system, was injected twice subcutaneously with a $2 \mathrm{hr}$ interval between injections into rats that had been starved for 4 days, and the rats were killed $6 \mathrm{hr}$ after the first injection. This treatment alone induced the enzyme (Fig. 7).

Chemical sympathectomy was achieved by an intravenous injection of 6hydroxydopamine (19) at a dose of $100 \mathrm{mg} / \mathrm{kg}$ body weight into rats that had been starved for 1 day. The rats were starved for a further 3 days and then fed starch or given $5 \mathrm{ml}$ of $20 \%$ glucose solution by stomach tube. They were killed at the times shown in Fig. 6. Chemical sympathectomy had no effect on enzyme induction (Fig. 6). 


\section{DISCUSSION}

In the present study we showed that feeding casein or starch to rats that had been starved for 4 days resulted in more than a 2 -fold increase in activity of duodenal alkaline phosphatase. However, the mechanisms of induction by casein and starch seem to be different because the enzyme activity in the blind loop of the intestine increases markedly within a short time after starch feeding, but not after casein feeding. This suggests that direct contact of the nutrient or the digestive products with the intestine or crossing of the products through the intestine is necessary for induction by casein but that the induction by starch is mediated by some other mechanism.

Intragastric administration or continuous intravenous infusion of glucose solution resulted in the same extent of increase in activity of alkaline phosphatase as starch feeding, indicating that a high blood glucose level is responsible for the induction. This conclusion is supported by the experiment shown in Fig. 4, in which when the blood glucose level remained unchanged under conditions in which intestinal absorption of glucose was completely inhibited by phlorizin no induction of enzyme was observed.

Hyperglycemia is known to stimulate insulin release from the pancreas by a direct action on the mechanism controlling release of stored insulin $(20,21)$ and stimulation of the parasympathetic nervous system via the hypothalamic glucoreceptor $(22,23)$. However, subcutaneous injection of insulin alone into rats after 4 days starvation had no effect on the enzyme induction, suggesting that the adaptive response resulted from hyperglycemia per se or hyperglycemia plus insulin release. As discussed later, stimulation of the parasympathetic nervous system caused by hyperglycemia appears the most important factor for enzyme induction.

There seems to be three types of adaptive response of intestinal enzyme activities. One is rapid (in hours), direct adaptive response of the epithelial cells (24); one is a slower (in several days) adaptive response that appears to act at the crypt cells with appearance of the response as the cells migrate up the villus (25); a third adaptive response is very slow (in several weeks) and has a long lag phase as seen in lactase induction by high lactose feeding (26).

Since induction of duodenal alkaline phosphatase occurs in several hours, it seems likely that it involves a direct effect on villus epithelial cells, although the exact mechanism is still unknown.

There is some evidence that the autonomic nervous systems regulate enzyme synthesis, as reported for the appearance of circadian rhythmic changes in phosphoenolpyruvate carboxykinase in the liver of fed rats (27) and induction of tyrosine transaminase in rat liver (18). Moreover, alkaline phosphatase in rat atria has been reported to be induced by subcutaneous injection of isoprenaline (28).

The effect of the autonomic nervous systems on the induction of duodenal alkaline phosphatase was tested in this study. In chemically sympathectomized rats, the extent of enzyme induction by intragastric administration of glucose solution or 
starch feeding was in the same order as that in sham-operated rats, indicating that the sympathetic nervous system has no relation to enzyme induction.

On the other hand, bilateral subdiaphragmatic vagotomy or hexamethonium injection prevented induction of duodenal alkaline phosphatase under conditions in which it was induced in sham-operated rats. Furthermore, carbachol injection alone markedly induced the enzyme. These facts strongly suggest that stimulation of the parasympathetic nervous system by either hyperglycemia or a cholinergic drug (carbachol) is important in induction of duodenal alkaline phosphatase.

The mechanism of the enzyme induction by casein feeding is still unknown and is now under study.

The authors are grateful to Dr. K. Morita, Department of Pharmacology, School of Medicine, The University of Tokushima for helpful discussion and advice.

\section{REFERENCES}

1) Hanna, S. D., Mircheff, A. K., and Wright, E. M. (1979): Alkaline phosphatase of basal lateral and brush border plasma membranes from intestinal epithelium. J. Supramol. Struct. Cell Biochem., 11, 451-466.

2) Hietanen, E. (1973): Interspecific variation in the levels of intestinal alkaline phosphatase, adenosine triphosphatase and disaccharidases. Comp. Biochem. Physiol., 46A, 359-369.

3) Raul, F., Simon, P., Kedinger, M., and Haffen, K. (1977): Intestinal enzymes activities in isolated villus and crypt cells during postnatal development of the rat. Cell Tiss. Res., 176, 167-178.

4) Tuba, J., and Dickie, N. (1955): The role of alkaline phosphatase in intestinal absorption. IV. The effects of various proteins on levels of the enzyme in intestinal mucosa. Can. J. Biochem. Physiol., 33, 88-92.

5) Naito, H., and Kadowaki, M. (1976): On the activity of alkaline phosphatase in intestinal mucosa from casein-fed rats. Agric. Biol. Chem., 40, 1435-1436.

6) Ono, K. (1974): The localization of alkaline phosphatase activity in the rat small intestinal epithelium after fat and protein feeding. Acta Histochem., 51, 124-137.

7) Tuba, J., and Dickie, N. (1954): The role of alkaline phosphatase in intestinal absorption. 11. The effects of various carbohydrates on levels of the enzyme in intestinal mucosa. Can. J. Biochem. Physiol., 32, 621-624.

8) Fujimoto, M., Kanaya, A., Nakabou, Y., and Hagihira, H. (1978): Circadian rhythm in the ornithine decarboxylase activity of rat small intestine. J. Biochem., 83, 237-242.

9) Forstner, G. G., Sabesin, S. M., and Isselbacher, K. J. (1968): Rat intestinal microvillus membranes. Biochem. J., 106, 381-390.

10) Lowry, O. H., Rosebrough, N. J., Farr, A. L., and Randall, R. J. (1951): Protein measurement with the Folin phenol reagent. J. Biol. Chem., 193, 265-275.

11) Ashwell, G. (1957): Arsenomolybdate method of Nelson. in Methods in Enzymology, Vol. 3, ed. by Colowick, S. P., and Kaplan, N. O., Academic Press, New York, pp. $85-86$.

12) Wilfred, G., and Rao, J. P. (1977): Effect of in vivo administration of insulin on hepatic alkaline phosphatase activity. Ind. J. Exp. Biol., 15, 627-630. 
13) Steiger, E., Vars, H. M., and Dudrik, S. J. (1972): A technique for long-term intravenous feeding in unrestrained rats. Arch. Surg., 104, 330-332.

14) Tsibulevskii, A. Yu., and Orlova, E. N. (1976): Physiological regeneration of the jejunal epithelium after bilateral subdiaphragmatic vagotomy in rats. Bull. Exp. Biol. Med., 81, 265-267.

15) Eletskii, Yu. K., Saidova, R. Z., and Shashirina, M. I. (1978): Morphology and function of the duodenal cholinergic nervous system under normal conditions and after subdiaphragmatic vagotomy. Bull. Exp. Biol. Med., 85, 829-832.

16) Yamada, S., Iwamoto, T., Kitagawa, H., and Kameyama, T. (1976): Dokuseigaku (in Japanese), Hirokawa Publ. Co., Tokyo, pp. 308.

17) Ikeda, Y. (1953): Yakubutsu Chishiryoshu (in Japanese), Nanzando Publ. Co., Tokyo, pp. 50.

18) Black, I. B., and Reis, D. J. (1971): Cholinergic regulation of hepatic tyrosine transaminase activity. J. Physiol., 213, 421-433.

19) Tutton, P. J. M., and Helme, R. D. (1974): The influence of adrenoreceptor activity on crypt cell proliferation in the rat jejunum. Cell Tissue Kinet., 7, 125-136.

20) Lacy, P. E. (1963): Electron microscopic and histochemical studies of the pancreas. Bull. N. Y. Acad. Med., 39, 807-811.

21) Grodsky, G. M. (1969): Factors influencing insulin release in vitro. Nucl. Sci. Abstr., 23, 1222.

22) Chhina, G. S., Anand, B. K., Singh, B., and Rao, P. S. (1971): Effect of glucose on hypothalamic feeding centers in deafferented animals. Am. J. Physiol., 221, 662-667.

23) Frohman, L. A., and Bernardis, L. L. (1971): Effect of hypothalamic stimulation on plasma glucose, insulin, and glucagon levels. Am. J. Physiol., 221, 1596-1603.

24) Rosensweig, N. S., Stifel, F. B., Zakim, D., and Herman, R. H. (1969): Time response of human jejunal glycolytic enzymes to a high sucrose diet. Gastroenterology, 57, 143146.

25) Rosensweig, N. S., and Herman, R. H. (1969): Time response of jejunal sucrase and maltase activity to high sucrose diet in normal man. Gastroenterology, 56, 500-505.

26) Bolin, T. D., Pirola, R. C., and Davis, A. E. (1969): Adaptation of intestinal lactase in the rat. Gastroenterology, 57, 406-409.

27) Nagai, K., Suda, M., and Nakagawa, H. (1973): Studies on the circadian rhythm of phosphoenolpyruvate carboxykinase activity in rats. 11. Effect of the autonomic nervous system on the rhythm in liver. J. Biochem., 74, 863-871.

28) Müller, E., Pearse, A. G. E., and Moss, D. W. (1971): The inducible alkaline phosphatase of rat heart. Biochem. J., 123, 895-900. 